\title{
BCL11B wt Allele
}

National Cancer Institute

\section{Source}

National Cancer Institute. BCL11B wt Allele. NCI Thesaurus. Code C91856.

Human BCL11B wild-type allele is located in the vicinity of $14 q 32.2$ and is approximately $102 \mathrm{~kb}$ in length. This allele, which encodes B-cell lymphoma/leukemia 11B protein, may be involved in the mediation of $\mathrm{T}$ cell differentiation, tumor suppression and p53-

mediated signaling. Aberrant expression is associated with adult T-cell leukemia/lymphoma. 